REGULAR ARTICLE

\title{
INCOME IMPACT OF PASTORALIST WOMEN PARTICIPATION IN ALOE VERA SOAP PRODUCTION IN SOUTHERN ETHIOPIA
}

\author{
Dida Golicha NURA *I (D), Sisay DEBEBE ${ }^{2}$
}

\author{
Address: \\ ${ }^{1}$ Jinka University, Faculty of Agriculture and Natural Resource, Department of Agricultural Economics, 165 and Jinka, \\ Southern Ethiopia \\ ${ }^{2}$ Arba Minch University, Faculty of Business and Economics, Department of Economics, 21 and Arba Minch, Southern \\ Ethiopia: \\ * Corresponding author: abbagolicha91@mail.com
}

\begin{abstract}
Commercial opportunity for indigenous Aloe Vera products appear to be increasing as there is a sustained demand from international as well as African market with high participation of women. However, its income impact on the livelihood of household is not yet addressed. Therefore, this study evaluated the income impact of pastoralist women participation in Aloe Vera soap production in Yabello district, Borana zone of Oromia, Ethiopia. Both primary and secondary data were collected from 200 sample households using semi-structured questionnaire. To analyse the data both descriptive and inferential statistics and Propensity Score Matching model were applied. The Propensity Score Matching was applied the required matching processes, covariate balancing and sensitivity analysis tests. The result shows that participation of women in Aloe Vera soap production has insignificant result with impact on household income. However, the propensity score matching also indicates average treatment effect on treated income is 45.693 Birr. Result of sensitivity analysis further shows that the estimated effects are insensitive to unobserved selection bias within gamma level used. Thus, Aloe Vera soap production should be encouraged for the pastoralist social wellbeing.
\end{abstract}

Keywords: Aloe Vera Soap production, Propensity Score Matching, Yabello, Southern Ethiopia JEL: B16, C21, O13

\section{INTRODUCTION}

According to many researchers commercial opportunity for indigenous Aloe Vera appear to be increasing as there is a sustained demand from international as well as regional market with high participation of women (Wren, 2008; Wren and Mamo, 2009). Aloe Vera is a semitropical plant that originated in the dry warm climate of Africa. It is a member of Lily family (liliaceae) and related to other Lily family such as the onion, garlic and turnip families. Its history dates back to the biblical times (Council, 1996-2002). There are about 400 species of aloe, but only five can be used as medicine. Today aloe plant is found worldwide and become high -ranking agent as an all-purpose herbal plant (Virdi, et al. 2012).

Aloe species are used as a medicine for animal and human in case of disease such as worms and internal parasites both for human and livestock's, malaria, for injured and scarred skin so as to fasten the healing process. Aloe sap also used for remedy of snack bite by mixing Aloe latex with certain proportions (1:40 ratio) of water and enforced to drink the one who have bitten as short as possible after the attack (Asmelash, 2017).

Internationally, the share of women in paid employment outside the agricultural sector has increased marginally. But in South Asia, North Africa and West Asia, employment opportunities remain very low. Approximately two-thirds of all employed women in developing countries work either as contributing family workers or as own-account workers, extremely vulnerable employment which lacks security and benefits. Gender difference in the labour force participation rates, unemployment rates and gender wage gaps are a persistent feature of global labour markets (UNDG, 2010).

In Africa participation of women in economic activities has been improving overtime. As present by Oyekanmi et al., (2014) African black soap is mostly hand crafted by village women who make the soap for themselves to support their families. This handmade African black soap which made with potash in small lots and from local materials includes alkali from cocoa pods ash, palm kernel oil, Aloe Vera and honey is found to be of high quality than the industrial produce soap. However, the production and the technique for the soap vary depending on the region of African where it is made.

According to Livingstone and Ruhindi. (2011), in the pastoralist communities women's groups play a vital role in economic contribution of family. In group they can act as supporters for individual loans, to mobilize the funds to expand or start a business, help to mitigate women's time poverty and reinforce existing social capital. This is essential because restrictions on women's mobility are a major constraint on their economic participation where women need to become empowered within harmonious, well-functioning families and societies. According to Handaragama et al. (2013) in Thunkama, the economic well-being of the family is initiated by women in the families since they perform a 
significant role in their family economy.

In Ethiopia, there is a participation of women groups in Bio-enterprise developments in sustainable wild harvest and domestication of indigenous Aloe species and gums product of non-timber forest products (NTFPs). Aloe is one of a vast growing plant species in Ethiopia even though the commercialization of this ample resource by residents and transient communities is very low (Demissew and Nordal, 2010).

As Wren and Mamo (2009) currently a few Bioenterprise are established at different parts of Ethiopia to utilize the natural resource in an area. Their goal is to contribute to the poverty reduction, economic empowerment and social wellbeing of pastoralists, particularly women. Example; rural women groups that participate in Aloe Vera soap production came from Tigray and Amhara region to Borana zone for cross visits organized to rural enterprises initiated by women groups for experience sharing.

As presented by Hurst, et al., (2012) in Borana community, women generate income for their family by establishing women's groups or savings cooperatives. Mostly NGOs such as CARE, Gayo and SOS Sahel provide financial support to women hoping to engage in petty trade businesses. These activities are purchasing sugar, alcohol, coffee, tobacco, butter, milk and tea leaves and then returning to the village to sell these items, thus earning a small profit. Women who live in close proximity to forests or wooded areas (special in Yabello and Arero districts) may use products from the forest to supplement their incomes. Organizations such as SOS Sahel encourage forest management and teach women how to use products from the forest such as aromatic wood product that is used as perfume, collect gum from trees and sell incense/myrrh to generate profit.

The Aloe Vera soap production established by SOS Sahel Ethiopia in Borana pastoral area in 2006 after they did an assessment on natural resource found in that area. Seed money was funded by the European (Milky union, 2017). Before this assessment Aloe plants taken as bush clearing but the result of assessment found that aloe is one of economical and medical wild tree in an area. Their intention was utilization of wild resource like aloes which is found in an area so as to improve livelihood of local community and social wellbeing of pastoralists, particularly women in sustainable manner. Indeed, it enables local community (like women, youth and people at different economic level) to participate in economic activities by starting Aloe Vera soap production opportunity.

Even though in most pastoral community, women roles are reproductive and they mostly work in the house like fetching water, collecting firewood, cooking food, cleaning and child care (Lasage et al., 2010), this project gives them chance to participate in productive activities to their family living. Today this project has becoming to expand into five districts of the zone.

As usually known the livelihood of pastoral and nomadic people are more relied on livestock (live animal and its product). Problem with this system in the study area is that they mostly depend on natural climate condition (rainfall).
However, the nature of rainfall becomes very erratic and there is a high drought expansion throughout the district of Borana zone including the study area. As Tilahun (2015), this drought causes shortage of feed and water for both livestock and human beings. Thus, severe death on livestock, and human hungry (food insure) is an end result of the drought. Therefore, what more important for this pastoral community is diversifying their basis of livelihood through utilization of available wild resource in an area with all participation of their local community without discrimination of sex and minor groups and people in all age. Aloes is one of those trees that identified as elaborated above.

Previous studies such as Teshome (2014) tried to address Aloe soap value chain initiatives and its effect on livelihood diversification strategy, by assessing the impact and determinants of participation in three kebele or peasant associations. Moreover, Tesfaye (2006), Demissew and Nordal (2010), Oda and Erena (2017), and Walker (2017) conducted study on the aloe species and distribution in different parts of Ethiopia including Yabello district. But, to the knowledge of this study the impact of Aloe Vera soap production particularly for women economic empowerment and income of household were not yet addressed. Therefore, considering aloe as one of commercial natural resource, and women as important human capital for Borana pastoral community, this study aims to fill the gaps by analysing the income impact of pastoralist women participation in Aloe Vera Soap production in Yabello district, Borana Zone of Oromia, Southern Ethiopia.

\section{DATA AND METHODS}

\section{Description of Study Area}

The study was conducted in Yabello district, Borana zone, southern Oromia State in Ethiopia. Yabello is located in the coordinates of $4^{\circ} 25^{\prime}-5^{\circ} 15^{\prime}$ North latitude and $37^{\circ} 50^{\prime}$ $38^{\circ} 50^{\prime}$ East longitude. The ecology of the zone is arid and semi-arid savannah (Beza, 2011), with an altitudinal range of 1000 -1600 masl (McCarthy et al, 2001). Borana zone rangelands are dominated by tropical savannah vegetation with varying proportions of open grasslands and perennial woody vegetation (Homann et al., 2007).

The mean annual daily temperature and a mean annual rainfall are around $19^{\circ} \mathrm{c}$ and below $600 \mathrm{~mm}$ respectively. It is frequently exposed to droughts that characterized as hot temperature and erratic rainfall. The erratic rainfall pattern causes vast area of the zone is not suitable for crop production. As (JICA, 2015; Tilahun, 2015), there are two rain season; long rainy ganna (from March to May) and short rainy Hagayya (from September to November) and the other remain months are dry season.

According to Demissew and Nordal (2010), the vegetation type in Borana zone was Acaccia-Commiphora woodland and bush land with scattered remnant forests. This vegetation type is particularly rich in Aloes and other lilies including quite a few endemic or near endemic Aloe species. The natural populations taking place in study area is found in Sidamo floristic region. 


\section{Research Design}

The study employed survey research of cross-sectional design. This cross-sectional survey study collected the data from study population at a single time from March to April of 2018 to examine the relationship between variables of interest. The study target population was both participant and non-participant women who are living in Yabello district of Oromia region, Ethiopia.

The study employed multi-stage sampling techniques that involve a combination of both simple random sampling and purposive sampling techniques.

In the first stage, on the basis of production of Aloe Vera soap out of the 12 kebeles of Yabello district, five sample kebeles were selected using stratification basis on the existence of intervention of Aloe Vera soap production in kebeles or not. The reason for this stratification is to have sample data from both kebeles of intervention and non-intervention of Aloe Vera soap production program. The first stratum was included women living in Aloe Vera soap production kebeles and a second stratum was accounted for non-participant women from the kebeles where production is not introduced yet.

Accordingly, Yabello district has only three kebeles (Dadim, Dida Yabello and Dikale) which produces Aloe Vera soap production; so that all three kebeles were selected purposively based on their production. From the other nine remain kebeles of which production is not yet started; two kebeles (Areri and Hara Awatu), for the case of taking as control group in order to reduce spillover effect for analysis of the impact of women participation in Aloe Vera soap, were selected purposively. This is because compared to others; those two kebeles are relatively more similar to intervention kebeles as they are on the same agro-ecology and on the same livelihoods basis (according to the interview of Yabello Pastoralist Development Office). Spillover is occurred due to interaction between participant and non-participant women live in the same village. Since this interaction is out of the control so taking some of the sample from the people outside the kebeles of Aloe Vera soap production is important.

On the second stage, sample respondents were selected randomly from each stratum on the basis of proportion to their population size. This is due to the homogeneity of population of study area.

Using the population data from (Yabello Pastoralist Development Office, 2017) the sample size was calculated since this data is not available on the CSA 2014 Ethiopian population projection. As in 2015/2016 Borana zone was separated into two zones and then many of district's and kebele's data were changed. By using the Yamane (1967) formula for sample size determination (Eq. 1) the study computed a total of representative 200 sample size.

$\mathrm{n}=\frac{N}{1+N(e 2)}$

\section{Method of Analysis}

The demographic and determinant characteristic of respondents were analysed using the combination of simple descriptive and inferential statistics. In addition, Propensity Score Matching model applied.
The propensity score matching of non-experimental methods of impact evaluation was used in ordered to assess the income impact of pastoralist women participation in the Aloe Vera soap production in the Yabello district of Borana zone, southern Ethiopia.

PSM builds a statistical comparison group that is based on a model of the probability of participating in the production, using observed characteristics. Participants are then matched on the basis of this probability, or propensity score, to nonparticipants. The average treatment effect of the production on treated is then calculated as the mean difference in outcomes across these two groups. PSM valid if two conditions are satisfied:

(a) Conditional Independence Assumption; (namely, that unobserved factors do not affect participation). It assumes that given a set of observable covariates $\mathrm{X}$ which are not affected by treatment, potential outcomes are independent of treatment assignment. This condition was tested using sensitive analysis.

(b) Sizable Common Support or Overlap: is about probability, propensity scores, across the participant and nonparticipant samples (Khandker et al., 2010). Common support assumption is central for this study analysis and both on support as well as off support households are found in the result. But, for all respondent overlap range is $0<\mathrm{P}(\mathrm{D}=1 \mid \mathrm{X})<1$. This ensures that persons with the same $\mathrm{X}$ values (observed covariates or characteristic X) have a positive probability of being both participants and non-participants. Consider the outcome of participants after participating in the production as $\mathrm{Y}_{1}$ and the outcome of nonparticipants or control households as $\mathrm{Y}_{0}$. This with-and-without group comparison measures the program's effect (participating in production) as $\mathrm{Y}_{1^{-}} \mathrm{Y}_{0}$. This difference is called impact of intervention. But this measure is not always give a right estimate of program effect because of the pre intervention situations of treated and control groups, the counterfeit comparison could yield an over- or underestimation of the program's effect.

The basic evaluation problem comparing outcomes $\mathrm{Y}$ across participant and non-participant individuals $\mathrm{i}$; is given by Eq. 2. Income is an outcome variable.

$\mathrm{Y}_{\mathrm{i}}=\alpha \mathrm{X}_{\mathrm{i}}+\beta \mathrm{T}_{\mathrm{i}}+\varepsilon_{\mathrm{i}}$

Where:

$\mathrm{T}$ is a dummy equal to 1 for those who participate and 0 for those who do not participate, $\mathrm{X}_{\mathrm{i}}$ is a set of other observed characteristics of the individual and perhaps (maybe) of her household and local environment and $\varepsilon$ is an error term reflecting unobserved characteristics that also affect Y.

The average treatment effect (ATE) of the program might be represented by Eq. 3 .

$\mathrm{D}=\mathrm{E}\left(\mathrm{Y}_{\mathrm{i}}(1) \mid \mathrm{T}_{\mathrm{i}}=1\right)-\mathrm{E}\left(\mathrm{Y}_{\mathrm{i}}(0) \mid \mathrm{T}_{\mathrm{i}}=0\right)$

Where: D is representing an impact of program.

The problem is that the participant and nonparticipant groups may not be the same prior to the intervention, so the expected difference between those groups may not be due entirely to program intervention. If, in equation 2 , one then adds and subtracts the expected 
outcome for nonparticipants had they participated in the program $\mathrm{E}(\mathrm{Yi}(0) \mid \mathrm{Ti}=1)$, or another way to specify the counterfactual one gets Eq. 4 - Eq. 6.

$\mathrm{D}=\mathrm{E}\left(\mathrm{Y}_{\mathrm{i}}(1) \mid \mathrm{T}_{\mathrm{i}}=1\right)-\mathrm{E}\left(\mathrm{Y}_{\mathrm{i}}(0) \mid \mathrm{T}_{\mathrm{i}}=1\right)+\left[\mathrm{E}\left(\mathrm{Y}_{\mathrm{i}}(0) \mid \mathrm{T}_{\mathrm{i}}=1\right)\right.$

$-\mathrm{E}\left(\mathrm{Y}_{\mathrm{i}}(0) \mid \mathrm{T}_{\mathrm{i}}=0\right)$

$\mathrm{D}=\mathrm{ATE}+\left[\mathrm{E}\left(\mathrm{Y}_{\mathrm{i}}(0) \mid \mathrm{T}_{\mathrm{i}}=1\right)-\mathrm{E}\left(\mathrm{Y}_{\mathrm{i}}(0) \mid \mathrm{T}_{\mathrm{i}}=0\right)\right]$

$\mathrm{D}=\mathrm{ATE}+\mathrm{B}$ (selection bias)

In Equations 4-6, ATE is $\left[\mathrm{E}\left(\mathrm{Y}_{\mathrm{i}}(1) \mid \mathrm{Ti}=1\right)-\mathrm{E}\left(\mathrm{Y}_{\mathrm{i}}(0)\right.\right.$ $\left.\left.\mid \mathrm{T}_{\mathrm{i}}=1\right)\right]$, that is, the average gain in outcomes of participants relative to nonparticipants, as if nonparticipating households were also treated. The ATE corresponds to a situation in which a randomly chosen household from the population is assigned to participate in the program, so participating and non-participating households have an equal probability of receiving the treatment $\mathrm{T}$. The term $\mathrm{B},\left[\mathrm{E}\left(\mathrm{Y}_{\mathrm{i}}(0) \mid \mathrm{T}_{\mathrm{i}}=1\right)-\mathrm{E}\left(\mathrm{Y}_{\mathrm{i}}(0) \mid \mathrm{T}_{\mathrm{i}}=\right.\right.$ $0)$ ], is the extent of selection bias that crops up in using $\mathrm{D}$ as an estimate of the ATE. Hence $\mathrm{E}\left(\mathrm{Y}_{\mathrm{i}}(0) \mid \mathrm{T}_{\mathrm{i}}=1\right)$, is unknown, the calculation of magnitude of selection bias is became difficult. As a consequence, it may impossible to know the exact difference in outcomes between the treated and the control groups. Therefore the basic objective of a sound impact assessment is then to find ways to get rid of selection bias $(\mathrm{B}=0)$ or to find ways to account for it. The solution for this problem is conditional independence assumption or unconfoundeness assumption. It means assuming that whether or not households or individuals receive treatment (conditional on a set of covariates, $\mathrm{X}$ ) were independent of the outcomes that they have. So B = 0 (selection bias is disappeared).

$(\mathrm{Yi}(1), \mathrm{Yi}(0)) \perp \mathrm{Ti} \mid \mathrm{Xi}$

Generally in independence assumption, the participant and non-participant groups must be the same in at least three ways. The average characteristics of the participant and non-participant groups must be identical in the absence of the program, the participant should not affect the nonparticipant group either directly or indirectly this is called (no spillovers) and the outcomes of units in the nonparticipant group should change the same way as outcomes in the participant group, if both groups were given the program (or not) Khandker et al., (2010).

\section{RESULTS AND DISCUSSION}

\section{Descriptive Statistic Results}

The study uses a total of 200 sample respondent data for analysis which was collected from Yabello district. Comprising 57 participants and 143 non-participants women in Aloe Vera soap production, as indicated in Table 2 .

Sex of the household head: According to the survey result obtained in the study area, 42 households are headed by female and the remains 158 households are male headed. Result of $\mathrm{chi}^{2}$-test found that the difference is statistical insignificant. This means participation is not different by which sex is headship of the family (Table 3 ).

Trade experience of respondent women: according to survey result obtained in the study area, 23.5 percent of respondent women had an experience of trading in different small business sectors. According to their response, the livelihood of study area community is depends on livestock, crops and livestock products whereas the crops and livestock products such as milk and butter are sold by women. From the comparison views between participant and non-participant women, there is higher frequency of trader in non-participant (29) than participant women (18). This difference is statistical positive and significant at $10 \%$ level.

Table 1: Definition of hypotheses variables and expected sign/s

\begin{tabular}{llll}
\hline Variable code & Variable name & Variable type & Expected sign \\
\hline COOP & Membership in other cooperative & Dummy & - \\
LAND & Size farm Land ow ned in hectares & Continuous & - \\
Sexhhh & Sex of household head & Dummy & - \\
EDURW & Educational level of women in year & Continuous & + \\
AGERW & Age of respondent woman in year & Continuous & + \\
FAMILYSIZE & Total family size of household & Continuous & + \\
Training & Access to training & Categorical & + \\
TRW & Respondent women trade experience & Dummy & + \\
CREDIT & Take credit & Dummy & + \\
EXTN & Numbers of extension contact & Continuous & + \\
TLU & Number of livestock has & Continuous & - \\
DROUGHT & Occurrence of drought & Dummy & - \\
AGEMARRIED & year of married for respondent women & Continuous & + \\
Labourforce & Number of labour force & Continuous & - \\
DISTANCE & Distance from nearest market in hrs. & Continuous & - \\
FASS: & Father Assets & Categorical & + \\
\hline
\end{tabular}


Table 2: Total sample of respondent

\begin{tabular}{lll}
\hline Variables & Freq. & Percent \\
\hline non-participant & 143 & 71.50 \\
Participant & 57 & 28.50 \\
Total & 200 & 100.00 \\
\hline Source: Own survey data, 2018
\end{tabular}

As Table (3) indicated, 47 percent of respondent women had extension contact per month and 0.5 percent of them had extension contact when asked. According to respondent reaction, agricultural development agents are advising them on agricultural production whereas the issue about resource management and how to work in cooperatives are not yet reached most of respondent by GOs. But, some NGOs are initiated to give them training on this concern. Majority of respondent had also credit services from different organization starting from their own women cooperative groups.

Moreover, the chi $^{2}$-test result from Table (3) shows extension contact and membership in other cooperative of respondent women is positive and significant at $5 \%$ and $1 \%$ level respectively. But, rest of the variables (credit, drought and Father's asset) are with chi $^{2}$-test of insignificant result even though there were some figurative differences among participant and nonparticipant women are seen.

Table (4) shows minimum, maximum, mean and std. deviation of age of respondent's women are 17, 80,39 and 14.083 years respectively. This table also reflected that mean age of participant women are 44.87 years and that of non-participants are 36.65 years. Which is also statistical negative and significant at $1 \%$ level as a witness of age difference between participant and non-participant. This result also tallied with the study hypothesis which stated that age is one of factor which increases women participation.

The minimum, maximum and mean age at which respondent women got marriage is 5, 30 and 16-17 years respectively. As one can see from Table (4), there is no that much difference between this two groups on their age of getting married both are on average at their $16^{\text {th }}$ years. Statistical t- test for this variable also shows no significant difference.

The educational level: Results of education show that on average respondent women are below grade one which means high illiteracy rate. Statistical t-test is also revealed insignificant result.

The minimum, maximum, mean and std. deviation of family size are 2, 12, 6-7 and 2-3 persons per household respectively. Mean family sizes of participant women (7.94) are greater than that of non-participant women (6.24). This difference is statistical negative and significant at $1 \%$ level. This result is also tallied with the study hypothesis which is stated that child is one of a driven force that pushes women towards productive works for their family wellbeing.

Table 3: Descriptive Statistics for categorical Variables

\begin{tabular}{|c|c|c|c|c|c|}
\hline Variables & $\begin{array}{l}\text { Total } \\
\text { Freq. }\end{array}$ & $\%$ & $\begin{array}{l}\text { Participant } \\
\text { Freq. }\end{array}$ & $\begin{array}{l}\text { Nonparticipant } \\
\text { Freq. }\end{array}$ & $\chi^{2}$ \\
\hline Sex of hhh & & & & & 1.357 \\
\hline Female & 42 & 21.0 & 15 & 27 & \\
\hline Male & 158 & 79.0 & 42 & 116 & \\
\hline TRW & & & & & $2.89 *$ \\
\hline Yes & 47 & 23.5 & 18 & 29 & \\
\hline No & 153 & 76.5 & 39 & 114 & \\
\hline Extension contact & & & & & $9.81 * *$ \\
\hline Weekly & 45 & 22.5 & 21 & 24 & \\
\hline Once in two week & 32 & 16.0 & 7 & 25 & \\
\hline Monthly & 94 & 47.0 & 23 & 71 & \\
\hline Once in a year & 28 & 14.0 & 6 & 22 & \\
\hline when asked & 1 & .5 & 0 & 1 & \\
\hline Taking credit & & & & & 0.02 \\
\hline Yes & 65 & 32.5 & 19 & 46 & \\
\hline No & 135 & 67.5 & 38 & 97 & \\
\hline Membership in other cooperative & & & & & $21.27 * * *$ \\
\hline YES & 110 & 55 & 46 & 64 & \\
\hline NO & 90 & 45 & 11 & 79 & \\
\hline Drought occurrence & & & & & 0.22 \\
\hline Sometimes & 18 & 9 & 6 & 12 & \\
\hline Frequently & 182 & 91 & 51 & 131 & \\
\hline Father asset & & & & & 1.40 \\
\hline Poor & 46 & 23.00 & 10 & 36 & \\
\hline Middle & 116 & 58 & 36 & 80 & \\
\hline Rich & 38 & 19 & 11 & 27 & \\
\hline
\end{tabular}

Source: Own survey data, 2018 
Table 4: Descriptive Statistics for continuous Variables

\begin{tabular}{|c|c|c|c|c|c|c|}
\hline Variables & $\begin{array}{l}\text { Participant } \\
\text { Mean } \\
\text { (std. d) }\end{array}$ & $\begin{array}{l}\text { Nonparticipant } \\
\text { Mean } \\
\text { (std. d.) }\end{array}$ & $\begin{array}{l}\text { Total } \\
\text { Min }\end{array}$ & $\operatorname{Max}$ & $\begin{array}{l}\text { Mean } \\
\text { (std. d.) }\end{array}$ & t-value \\
\hline AGERW & $\begin{array}{l}44.87 \\
(11.51)\end{array}$ & $\begin{array}{l}36.65 \\
(14.35)\end{array}$ & 17 & 80 & $\begin{array}{l}39.00 \\
(14.083)\end{array}$ & $-3.85 * * *$ \\
\hline AGEMARRIED & $\begin{array}{l}16.87 \\
(2.42)\end{array}$ & $\begin{array}{l}16.23 \\
(3.04)\end{array}$ & 5 & 30 & $\begin{array}{l}16.41 \\
(2.88)\end{array}$ & -1.43 \\
\hline EDURW & $\begin{array}{l}0.08 \\
(0.47)\end{array}$ & $\begin{array}{l}.16 \\
(.81)\end{array}$ & 0 & 5 & $\begin{array}{l}.14 \\
(.73)\end{array}$ & 0.64 \\
\hline TLU & $\begin{array}{l}11.20 \\
(9.85)\end{array}$ & $\begin{array}{l}15.46 \\
(16.60)\end{array}$ & .3 & 121.05 & $\begin{array}{l}14.25 \\
(15.09)\end{array}$ & $1.8^{*}$ \\
\hline Family size & $\begin{array}{l}7.94 \\
(2.22)\end{array}$ & $\begin{array}{l}6.24 \\
(2.51)\end{array}$ & 2 & 12 & $\begin{array}{l}6.73 \\
(2.55)\end{array}$ & $-4.48 * * *$ \\
\hline Labourforce & $\begin{array}{l}2.24 \\
(1.02)\end{array}$ & $\begin{array}{l}1.90 \\
(.56)\end{array}$ & 0 & 6 & $\begin{array}{l}2.00 \\
(.73)\end{array}$ & $-3.03 * * *$ \\
\hline Monthly income & $\begin{array}{l}1019.3 \\
(664.52)\end{array}$ & $\begin{array}{l}938.46 \\
(645.45)\end{array}$ & 200 & 5000 & $\begin{array}{l}961.50 \\
(650.3)\end{array}$ & -0.79 \\
\hline Land & $\begin{array}{l}1.09 \\
(.69)\end{array}$ & $\begin{array}{l}1.115 \\
(.71)\end{array}$ & 0 & 5. & $\begin{array}{l}1.108 \\
(.708)\end{array}$ & 0.20 \\
\hline Distance & $\begin{array}{l}1.61 \\
(.94)\end{array}$ & $\begin{array}{l}2.16 \\
(.80)\end{array}$ & 0 & 4. & $\begin{array}{l}2.007 \\
(.877)\end{array}$ & $4.1 * * *$ \\
\hline
\end{tabular}

Source: own survey data, 2018

According to the Table (4), the minimum, maximum and mean of labour force person per household is 0,6 , and 2 respectively. The mean labour force of both family of participant and non-participant women are approximately 2 person which is too much less than mean family size (67). Statistical t-test for labour force is also revealed negative and significant result at $1 \%$ level. This result also tallied with the study hypothesis.

According to UN (2017) on average family size in Ethiopia is 4.6person per household. They also said that "Small average household sizes, fewer than three persons per household are concentrated in Europe and Northern America, whereas large average household sizes, five or more persons per household are observed across much of Africa and the Middle East". Thus, the family size of the respondent in both cases is that of Ethiopian national level and within the range of most African and Middle East countries.

Table (4) also shows the minimum, maximum, mean and str. deviation of average estimated household income per month are 200, 5000, 961.50 and 650.3Birr respectively. But, mean monthly income of participants and non-participants women households is 1019.3 and 938.46 Birr respectively. It show that there is some what difference on mean monthly income earning of participants and non-participant in which the participant's mean income is greater than that of non-participants' households even though this difference is statistical insignificant.

The possible reason for this difference is that; according to the respondents' responses of participant women they were benefited for being participant of this production, they are always gaining the acting of learning and exercising experience from different organization such as local, national and international NGOs and GOs. Beside this, the participant themselves formed different form of cooperatives like butter, mirt stove, milk cooperative and also joining into other formed cooperatives. This all training and learning process are gradually developed among participant as they come together as co-workers. In monetary benefit, participants also had a lot of saved deposited money on account and some capital asset inform of cooperative.

But, according to participant women responses their problem was: there is no dividend sharing to members that cause them disincentive to work. And another problem that they were raised as hindering factor for this production was problem of input supplied especially caustic soda and cooking oil. Many women said that, if they were getting these ingredients (inputs) individual, they will produce soap as individual business.

The minimum, maximum and mean total tropical livestock units are $0.3,121.05$ and 14.254 respectively. The difference in this characteristic is also similar to household monthly income. There is gap between minimum and maximum which explained in std. deviation (15.09) of mean (14.25) total tropical livestock unit. As result indicated the mean and standard deviation of participant women household livestock holding is smaller than that of non-participant women household. This result is statistical positive and significant at $10 \%$ level. This result also supports the study hypothesis.

The minimum, maximum and mean distribution of land is $0.0,5$ and 1.1087 hectares respectively. The mean land holding of participant (1.09 hectares) is below that of non-participant (1.115 hectares) but this difference is statistical insignificant. The mean land holding of total respondent is below that of national level. As national level land use survey shows the average household farm size in Ethiopia is 1.37 hectares, but its varies by place of residence and the gender of the household head (CSA, 2013).

The mean distance of respondent from the nearest market is $2 \mathrm{hrs}$ on foot. This result is also positive and 
significant at $1 \%$ level where on average it take less hours for participants women to go a nearest market. But standard deviation result revealed that there is somewhat higher variation within participant (.94) than nonparticipant (.80). This means, compared to nonparticipant, not all participants were nearby market. It is tallied with the study hypothesis.

\section{Propensity Score Matching Model Results}

The "sum myscore" command was used to check/ summarize the propensity score (Table 5).

As propensity score is a probability, it has to be in the interval of $[0: 1]$. Hence, the average probability of respondent women to participate in the Aloe Vera soap production for all the individuals is $28.5 \%$.

Check Range of Common Support

Psgraph test for the common support was used to check the extent to which distributions of propensity scores in treatment (participants) and comparison (nonparticipants) groups are overlapped from logistic regression of propensity score matching model.

Note: the common support option has been selected. The region of common support is [.00411911, $.97775877]$.This assumption of common support was also checked graphical as following; if an assumption of common support holds, there must be an overlap of the propensity scores of the participants and non-participants.

That's why the Figure (1) depicted as three colour of blue, red and green. The blue and red colours are on common support region, but green colour indicated the propensity score out of common support regions. In each class of the propensity score there is a certain number of non-treated and treated individuals as well.

\section{Check Balancing Property}

Step 1: Identification of the optimal number of blocks. The final number of blocks is 5 . This number of blocks ensures that the mean propensity score is not different for treated (participants) and controls (non-participants) in each blocks. The Stata was used t-tests to determine whether each covariate is balanced within each block.

Step 2: Test of balancing property of the propensity score across groups. It should be needed to check balancing before trusting the ATT estimation. This was the test of whether mean of propensity score is equal in treatment and comparison groups within each quintile. Therefore, the Stata result of both steps revealed that the balancing property is satisfied in each blocks for each covariates.

Table (6) shows the inferior bound, the number of treated and the number of controls for each block under the assumption of common support. And in this case, total 190 respondents are on common support of which 133 are non-participant women and 57 are participant women.

Figure (2) shows the distribution of the all household with respect to their estimated propensity score. Accordingly, most of the treatment households are found partially in the middle and partially in the right side of the distribution. On the other hand, most of the control households are partially found in the center and partially in the left side of the distribution.

Of course, two conditions were identified and as well satisfied, the success of the matching for each of the independent variables was also tested from the matching algorithm of propensity score after the choice of matching algorithm estimator.

Choice of Matching Algorithm

Note: There is no universal best strategy among matching algorithm of propensity score matching but the focus should be given on the trade-off between bias and variance/efficiency.

For instance, According to Caliendo and Kopeinig (2005) on their review of "practical guidance for the implementation of propensity score matching", one way of assessing the quality of matching is t-test of standard bias for all covariates as all covariates should be balanced. In this case of study on hand, as indicated in Tables ( 7 and $8)$, the test revealed that all covariates are balanced after matching. Again, Caliendo and Kopeinig (2005) offered that the joint significance test was found another method to assess matching quality. And they elaborated this joint significant as this; the best matching result was found in such away as before matching there might be significant difference in all covariates, and should be the insignificant difference result existed after matching or for matched sample case.

Table 5: Summary of pscore

\begin{tabular}{llllll}
\hline Variable & Obs & Mean & Std. Dev. & Min & Max \\
\hline Total household & 200 & .285 & .3229254 & $3.36 \mathrm{e}-06$ & .9857269 \\
non-participant & 143 & .1371315 & .2047364 & $3.36 \mathrm{e}-06$ & .9857269 \\
Participant & 57 & .6559683 & .2614782 & .0041191 & .9777588 \\
\hline
\end{tabular}

Source: own survey result, 2018

Table 6: Inferior block of propensity score

\begin{tabular}{llll}
\hline Inferior of block of pscore & $\begin{array}{l}\text { PARTALS } \\
\text { non-participant }\end{array}$ & Participant & Total \\
\hline .0041191 & 104 & 4 & 108 \\
.2 & 15 & 6 & 21 \\
.4 & 8 & 12 & 20 \\
.6 & 2 & 12 & 14 \\
.8 & 4 & 23 & 27 \\
Total & 133 & 57 & 190 \\
\hline
\end{tabular}

Source: Model result, 2018 


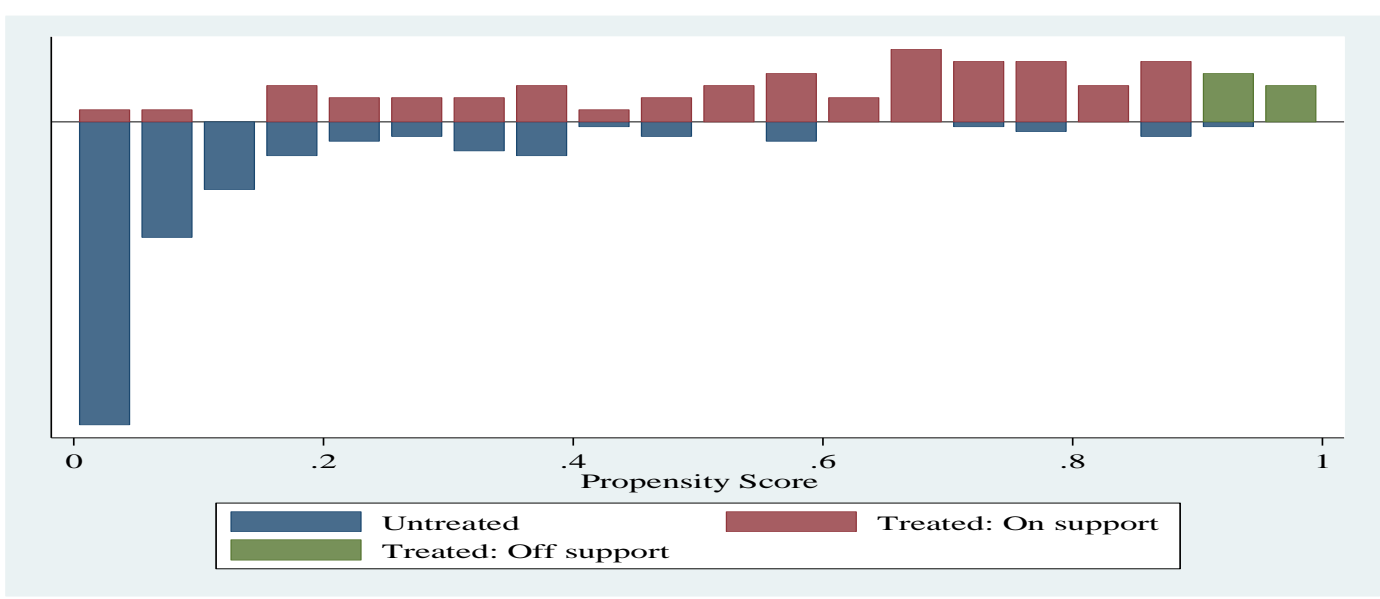

Source: own survey result, 2018

Figure 1: Psgraph between treated versus untreated groups

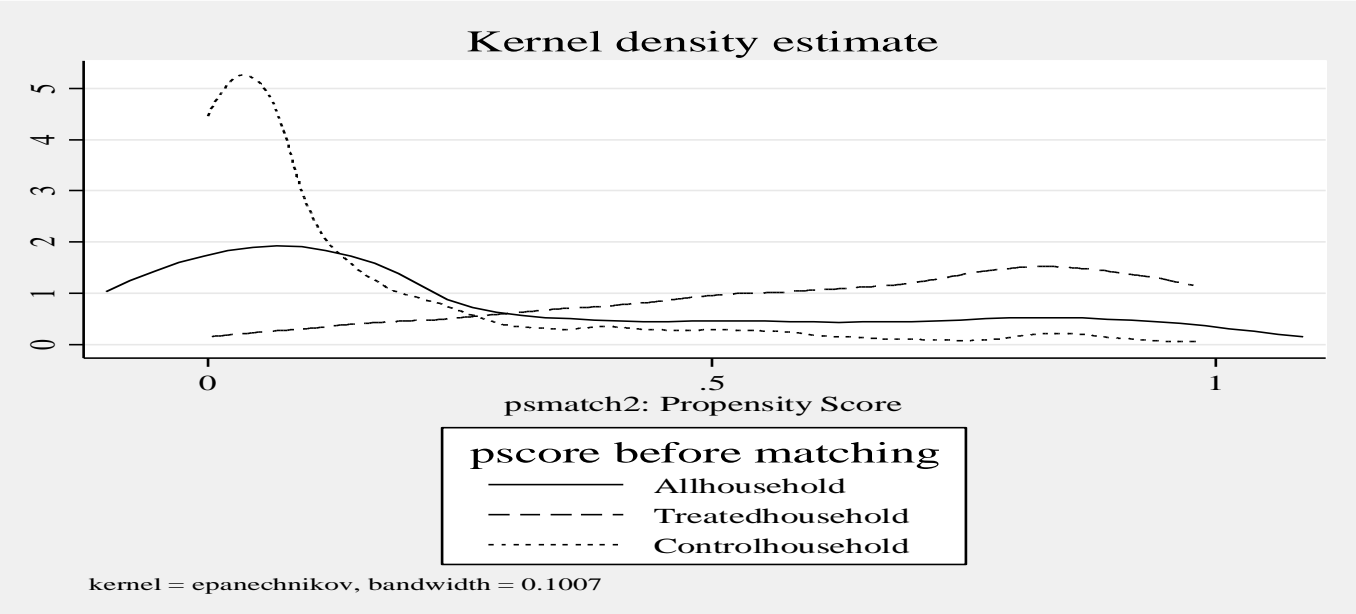

Source: own survey result, 2018

Figure 2: Pscore before matching

In line with this connotation, the joint significant test of different matching algorithms for this study was taken as this and the result was found, in Table (7), that all used algorithm satisfied to some extent the test condition even though the difference was found in the level of percentage significance. Accordingly, the result of kernel band width (0.25) has the lowest Pseudo- $\mathrm{R}^{2}$ and all covariates are balance after matching for matched sample among all algorithm. Similarly, (Dehejia and Wahba, 2002) noted that, the choice of a matching estimator was based on different criteria like equal means test (balancing test of covariates), lowest pseudo-R2 and largest numbers of matched sample size.

Therefore, the matching algorithm with highest sample size matched, insignificant matched sample or equal means and with the lowest Pseudo- $\mathrm{R}^{2}$ value for matched sample, among the other used matching algorithm for this study is kernel band width (0.25) as indicated in Table (7).

Covariate Imbalance Tests (before and after matching) and Graphing

According to the summary of (Leuven and Sianesi, 2003) on psmatch 2 module; the main focus of this test was; for each variable t-test the equality of means before and after matching, standardized \% bias before and after, and achieving \% reduction in |bias| is found to be important. And as long as overall significance concerned; pseudo $\mathrm{R}^{2}$ from logistic of treatment on covariates before matching and on matched samples, p-values of the likelihood-ratio test of joint insignificance of covariate before and after matching and summary indicators of the distribution of |bias| before and after are critically issues. Accordingly, for these point illustrations, pstest was applied and discussed for this study as follows:

The Table (8) show that a t-test on the hypothesis that the mean value of each variable is the same in the treatment group and the non-treatment group. It was done before and after matching.

Moreover, a bias before and after matching was calculated for each variable and the change /reduction/ in this bias was indicated. In this table, one can see the difference of the values of the exogenous variables between the two groups before matching.

With matching, all covariates are shown us, no significance mean difference after matching as it indicated by the p-value of test in Table (8). Caliendo and 
Kopeinig (2005) "before matching differences are expected, but after matching the covariates should be balanced in both groups and hence no significant differences should be found".

Also standard bias reduction result in Table (8) revealed that the differences between treatment group and non-treatment group are reduced for many variables where exception was found in the variables such as training, sexhhh (sex of household head); family size and AGEMARRIED (age at first married). Even though in the case of these variables the difference between two groups were not reduced, but these variables are statistical significant effect on participation as it revealed.

Therefore, pstest indicated all variables are satisfied the insignificance test of after matching which means there is no mean difference after matching for each variables are balanced.

The Table (9) description was about the joint significance, taking together all predictors variable, that explained by Pseudo- $R 2$ and $\mathrm{p}>\mathrm{chi} 2$. The pseudo- $R^{2}$ indicates how well the regressors $\mathrm{Xs}$ explain the participation probability. As it was explained, after matching there should be no systematic divergences in the distribution of covariates between both groups. This means for the joint significance; $p>c h i 2$ value before matching might be statistical significant, and $\mathrm{p}>\mathrm{chi} 2$ value after matching (for matched sample) should be statistical insignificant.

Accordingly, test in Table (9) was also illustrated that ( $p>c h i 2$ is 0.000 for unmatched sample) so there is not to be rejection before matching, and ( $p>c h i 2$ is 0.937 for matched) there is to be highly rejection after matching which was an expected result of this regression.

Figure (3) portrays graphically the distribution of mean score of each of explanatory variable for the participant and non-participants of unmatched and matched. And it shows the standardized $\%$ bias across covariates.
Hence, the conclusion from pstest, in all foresaid whether graphically or table from, was that the propensityscore of kernel band width (0.25) matching was the best matching algorithm for this data. This means it's the best algorithm through which possible to generate a control group which is similar enough to the treatment group to be used for the ATT estimation.

Therefore, based on this assumption of bias and variance/efficiency trade-off as well pstest, this study estimated ATT using propensity score matching of kernel band width (0.25) algorithm in order to look at the effect of women participation in Aloe soap production on the outcome variable which is household income as following.

Hence, the results of propensity score matching of kernel band width (0.25) matching indicated that the ATT difference on score monthly income of household of women between matched respondents' were, on average, 45.693 Birr which is a positive result. Even though this result is not significant, the positive sign implies that on average monthly income of participant's women households are better than that of non-participant women as similar to the result already explained in the descriptive statistic (Table 4). According to respondent responses the participant women are getting benefit from different angels. One, they can get soap in kind at home from the residual of marketed soap. This will reduce their household expenditure from home consumption. Second, participant also had a training from different NGOs in relation to their production and from that training NGOs give some cash money as an incentive. Third, coming together participant formed $i k u b$ group and other women association like milk cooperative, and through all this they could winning monetary benefit. But, all these, they sold their soap 4 to 6 days within a week at market even though that profit is collected inform of cooperative in bank deposit and/or inform of capital asset of cooperative.

Table 7: Comparison of different matching al gorithm estimators

\begin{tabular}{llllll}
\hline $\begin{array}{l}\text { Matching estimator } \\
\text { nearest neighbour }\end{array}$ & balancing test* & PS R & LR $\chi^{2}$ & Prob> $\chi^{2}$ & matched N \\
\hline $\mathrm{NN}(1)$ & 16 & 0.101 & 15.92 & 0.459 & 200 \\
$\mathrm{NN}(2)$ & 16 & 0.069 & 10.98 & 0.811 & 200 \\
$\mathrm{NN}(3)$ & 15 & 0.070 & 11.04 & 0.807 & 200 \\
$\mathrm{NN}(4)$ & 16 & 0.074 & 11.62 & 0.770 & 200 \\
$\mathrm{NN}(5)$ & 16 & 0.068 & 10.73 & 0.826 & 200 \\
radius caliper & & & & & \\
0.1 & 16 & 0.055 & 8.69 & 0.925 & 200 \\
0.01 & 16 & 0.102 & 8.52 & 0.932 & 173 \\
0.25 & 16 & 0.061 & 9.67 & 0.883 & 200 \\
0.5 & 16 & 0.110 & 15.27 & 0.644 & 193 \\
kernel matching & & & & & \\
band width0.1 & 16 & 0.068 & 10.80 & 0.822 & 200 \\
band width 0.01 & 16 & 0.085 & 7.09 & 0.972 & 173 \\
band width 0.25 & 16 & 0.053 & 8.38 & 0.937 & 200 \\
band width 0.5 & 15 & 0.083 & 13.08 & 0.667 & 200 \\
\hline Source: Model result, 2018 & & & &
\end{tabular}

Source: Model result, 2018

* Number of explanatory variables with no statistically significant mean differences between the matched samples. 
Table 8: pstest table

\begin{tabular}{|c|c|c|c|c|c|c|c|c|}
\hline \multirow[t]{2}{*}{ Variables } & \multirow{2}{*}{$\begin{array}{l}\text { Unmatched } \\
\text { Matched }\end{array}$} & \multicolumn{2}{|l|}{ Mean } & \multicolumn{2}{|c|}{ \%reduct } & \multicolumn{2}{|l|}{ t-test } & \multirow[t]{2}{*}{$\mathrm{V}(\mathrm{T}) / \mathrm{V}(\mathrm{C})$} \\
\hline & & Treated & Control & \%bias & bias & $\mathrm{T}$ & $\mathrm{p}>|\mathrm{t}|$ & \\
\hline \multirow[t]{2}{*}{ Sexhhh } & $\mathrm{U}$ & .73684 & .81119 & -17.7 & & -1.16 & 0.246 & \\
\hline & M & .73684 & .71208 & 5.9 & 66.7 & 0.29 & 0.770 & \\
\hline \multirow[t]{2}{*}{ AGERW } & $\mathrm{U}$ & 44.877 & 36.65 & 63.2 & & 3.86 & 0.000 & 0.64 \\
\hline & M & 44.877 & 42.39 & 19.1 & 69.8 & 1.23 & 0.220 & 1.34 \\
\hline \multirow[t]{2}{*}{ TRAINING } & $\mathrm{U}$ & 3 & 1.8112 & 90.0 & & 5.97 & 0.000 & 1.40 \\
\hline & M & 3 & 2.8041 & 14.8 & 83.5 & 0.80 & 0.426 & 1.46 \\
\hline \multirow[t]{2}{*}{ AGEMARRIED } & $\mathrm{U}$ & 16.877 & 16.231 & 23.5 & & 1.43 & 0.153 & 0.63 \\
\hline & M & 16.877 & 16.63 & 9.0 & 61.8 & 0.53 & 0.599 & 0.87 \\
\hline \multirow[t]{2}{*}{ FAMILYSIZE } & U & 7.9474 & 6.2378 & 72.0 & & 4.48 & 0.000 & 0.78 \\
\hline & M & 7.9474 & 8.0991 & -6.4 & 91.1 & -0.33 & 0.741 & 0.71 \\
\hline \multirow[t]{2}{*}{ TLU } & $\mathrm{U}$ & 11.204 & 15.47 & -31.2 & & -1.81 & 0.071 & $0.35 *$ \\
\hline & M & 11.204 & 11.856 & -4.8 & 84.7 & -0.36 & 0.721 & 1.06 \\
\hline \multirow[t]{2}{*}{ LAND } & $\mathrm{U}$ & 1.0921 & 1.1154 & -3.3 & & -0.21 & 0.835 & 0.94 \\
\hline & M & 1.0921 & .97823 & 16.1 & -389.2 & 0.99 & 0.326 & $1.75^{*}$ \\
\hline \multirow[t]{2}{*}{ Labourforce } & $\mathrm{U}$ & 2.2456 & 1.9021 & 41.7 & & 3.04 & 0.003 & $3.33 *$ \\
\hline & M & 2.2456 & 2.1187 & 15.4 & 63.1 & 0.85 & 0.397 & $4.69 *$ \\
\hline \multirow{2}{*}{ TRW } & $\mathrm{U}$ & 1.6842 & 1.7972 & -25.8 & & -1.71 & 0.090 & 1.35 \\
\hline & M & 1.6842 & 1.7318 & -10.9 & 57.9 & -0.55 & 0.580 & 1.10 \\
\hline \multirow[t]{2}{*}{ EXTN } & $\mathrm{U}$ & 2.2456 & 2.6573 & -40.5 & & -2.65 & 0.009 & 1.26 \\
\hline & M & 2.2456 & 2.3087 & -6.2 & 84.7 & -0.32 & 0.752 & 1.04 \\
\hline \multirow[t]{2}{*}{ CREDIT } & $\mathrm{U}$ & 1.6667 & 1.6783 & -2.5 & & -0.16 & 0.875 & 1.03 \\
\hline & M & 1.6667 & 1.6497 & 3.6 & -45.2 & 0.19 & 0.851 & 0.98 \\
\hline \multirow[t]{2}{*}{ DROUGHT } & $\mathrm{U}$ & 2.8947 & 2.9161 & -7.3 & & -0.47 & 0.636 & 1.24 \\
\hline & M & 2.8947 & 2.8285 & 22.5 & -210.1 & 1.02 & 0.310 & 0.66 \\
\hline \multirow{2}{*}{ COOP } & $\mathrm{U}$ & 1.193 & 1.5524 & -79.6 & & -4.86 & 0.000 & 0.64 \\
\hline & M & 1.193 & 1.2341 & -9.1 & 88.6 & -0.53 & 0.596 & 0.87 \\
\hline \multirow[t]{2}{*}{ DISTANCE } & $\mathrm{U}$ & 1.6132 & 2.164 & -63.0 & & -4.17 & 0.000 & 1.38 \\
\hline & M & 1.6132 & 1.6205 & -0.8 & 98.7 & -0.04 & 0.967 & 1.00 \\
\hline \multirow[t]{2}{*}{ EDUCRW } & $\mathrm{U}$ & .08772 & .16084 & -11.0 & & -0.64 & 0.524 & $0.34 *$ \\
\hline & M & .08772 & .04868 & 5.9 & 46.6 & 0.48 & 0.635 & 1.40 \\
\hline \multirow[t]{2}{*}{ FASS } & $\mathrm{U}$ & 2.0175 & 1.9371 & 12.6 & & 0.79 & 0.430 & 0.85 \\
\hline & M & 2.0175 & 2.0235 & -0.9 & 92.6 & -0.05 & 0.961 & 0.75 \\
\hline
\end{tabular}

Source: Model result, 2018

* If variance ratio outside $[0.59 ; 1.70]$ for $\mathrm{U}$ and $[0.59 ; 1.70]$ for $\mathrm{M}$

Table 9: Joint significance test of psmatch2

\begin{tabular}{llllll}
\hline Sample & Ps R2 & LR chi2 & p>chi2 & MeanBias & MedBias \\
\hline Unmatched & 0.448 & 107.10 & 0.000 & 36.6 & 28.5 \\
Matched & 0.053 & 8.38 & 0.937 & 9.5 & 7.7 \\
\hline
\end{tabular}

Source: Model result, 2018

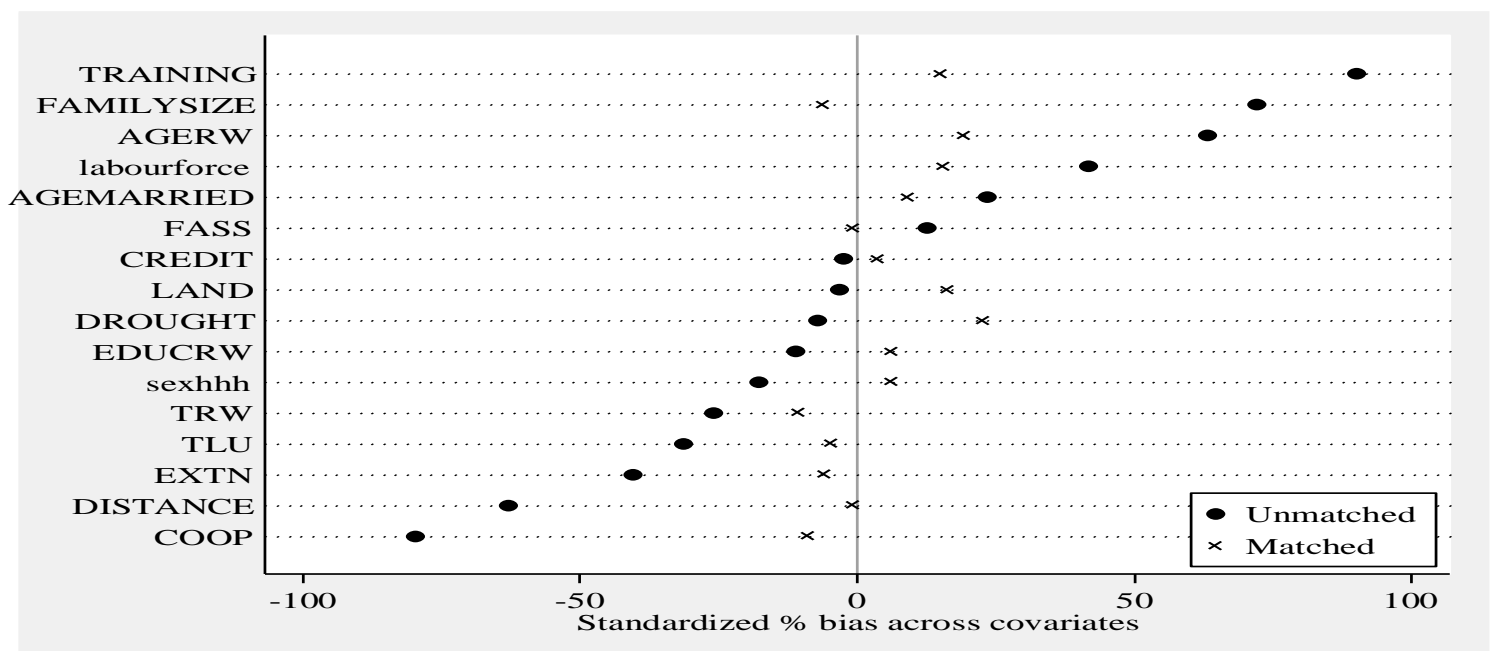

Source: own survey result, 2018

Figure 3: pstest graph 
Table 10: ATT of participation of the women on income and CEI

\begin{tabular}{llllll}
\hline Variable & Sample & Treated & Controls & Difference & T-stat \\
\hline MONTHLYINCOM & Unmatched & 1019.3 & 938.462 & 80.837 & 0.79 \\
& ATT & 1019.3 & 973.605 & 45.693 & 0.27 \\
\hline
\end{tabular}

Note: S.E. does not take into account that the propensity score is estimated.

Source: model result, 2018

Table 11: Bootstrap standard error

\begin{tabular}{|c|c|c|c|c|c|}
\hline & Observed & Bootstrap & & & Normal-based \\
\hline & Coef. & Std. Err. & $\mathrm{Z}$ & $\mathrm{P}>|\mathrm{z}|$ & [95\% Conf. Interval] \\
\hline & -10.61338 & 139.9015 & -0.08 & 0.940 & -284.8153 \\
\hline
\end{tabular}

Source: model result, 2018

Table 12: Rosenbaum bounds for outcome variable ( $\mathrm{N}=200$ matched pairs)

\begin{tabular}{lcllllll}
\hline Outcome Variable & Gamma & sig+ & sig- & t-hat+ & t-hat- & CI+ & CI- \\
\hline Monthly income & 1 & 0 & 0 & 850 & 850 & 800 & 900 \\
& 1.1 & 0 & 0 & 800 & 900 & 800 & 900 \\
& 1.2 & 0 & 0 & 800 & 900 & 800 & 900 \\
& 1.3 & 0 & 0 & 800 & 900 & 800 & 950 \\
& 1.4 & 0 & 0 & 800 & 900 & 750 & 1000 \\
& 1.5 & 0 & 0 & 800 & 900 & 700 & 1000 \\
\hline
\end{tabular}

* gamma - log odds of differential assignment due to unobserved factors

sig+ - upper bound significance level

sig- - lower bound significance level

t-hat+ - upper bound Hodges-Lehmann point estimate

t-hat- - lower bound Hodges-Lehmann point estimate

$\mathrm{CI}+\quad$ - upper bound confidence interval $(\mathrm{a}=.95)$

CI- - lower bound confidence interval $(\mathrm{a}=.95)$

\section{Robust test}

The S.E. does not take into account that the propensity score is estimated (Table 10). This is because the estimated variance of the treatment effect also include the variance due to the estimation of the propensity score, the imputation of the common support, and possibly also the order in which treated individuals are matched. Caliendo and Kopeinig (2005), thus, one way to deal with this problem is to use bootstrapping. According to Schmidheiny (2016) the bootstrap takes the sample (the values of the independent and dependent variables) as the population and the estimates of the sample as true values Sensitivity Analysis of Pscore Matching

As long the PSM method are concerned for the impact analysis, it might needed to analysis sensitivity of ATT estimation to any unobserved covariates that might introduce the hidden /endogeneity bias. Hence, as the Table (12) indicated the Rosenbaum bounds test was applied to evaluate the sensitivity of how the changing values of a parameter gamma, $\Gamma$, would influence the significance of the results obtained from the matching analysis. According to many literature like If $\Gamma=1$, then, hidden bias is zero.

The result in Table (12) revealed that for all chosen gamma level $(1,1.1,1.2,1.3,1.4$ and 1.5), the upper and lower bound significance level, upper and lower bound of Hodges-Lehmann point estimate and upper and lower bound of confidence interval for outcome variable. The result of upper and lower bound significance level is significant for outcome variable. The result of upper bound Hodges-Lehmann point and confidence interval is decreasing and the lower bound in both cases is increasing.
This witnessed that, the computed ATTs are relatively insensitive to unobservable covariates that might introduce as hidden bias.

\section{CONCLUSION AND RECOMMENDATIONS}

The study concluding and recommending it's finding as follows; the first major problem in production of Aloe Vera soap was input (caustic soda and cooking oil) availability since production is impossible without these inputs. First, caustic soda is only found at national level market which is also just by order, and there is highly problem with market supply and market price of cooking oil. In order to skip this problem of inputs so far aloe soap producers have been organized under milk union and then it facilitate inputs supply and product market of those primary cooperative. District trade office also sometime with very little attention gives them a few litre of oil to those cooperative which is not that much interesting and initiating them for higher level production. Therefore, based on the income impact of this production, the NGOs, government office such as cooperative, trade office, and management at zone and district level should aware of this opportunity and facilitate the input supply (caustic soda and cooking oil) for those primary cooperative, and also for any woman demanding individual in production, and letting this production to goes beyond cooperative to individual level.

Overall according to the impact result of propensity score matching of kernel band width (0.25) result revealed, participation of women in Aloe Vera soap has a positive impacts on the household income even though the result is 
statistical insignificant. Therefore, non-participant women should be encouraged to have an opportunity to participate more in such productive activities. But, the insignificant result might be due to the study estimation method and data, the study also recommend other researcher to conduct further research taking this study as a base line. Remind, from theory of population growth, Esther Boserup was quoted as "more people there are, the more hands there are to work". Therefore, so is women role for total wellbeing of community at large.

\section{REFERENCES}

ASMELASH, G. T. (2017). The Types of Aloe species and their Multi- Function in Southern Ethiopia the Cases of Hammer District. International Journal of Environmental Sciences and Natural Resource, 3. https://juniperpublishers.com/ijesnr/pdf/IJESNR.MS.ID. $\underline{555619}$

BEZA, T. A. (2011). Land Cover Dynamics in Savanna Ecosystem of Borana Ethiopia. Institute for Geoinformatics University of Münster. https://run.unl.pt/bitstream/10362/8283/1/TGEO0049.

CALIENDO, M. \& KOPEINIG, S. (2005). Some Practical Guidance for the Implementation of Propensity Score Matching IZA DP No. 1588. ftp.iza.org/dp1588

COUNCIL, I. A. (1996-2002). Aloe Vera a Long, Illustrious History -Dating From Biblical Times.

CSA (2013). Ethiopia Rural Socioeconomic Survey (ERSS) Survey Report.

DEHEJIA, R. H. \& WAHBA, S. (2002). Propensity scorematching methods for non-experimental causal studies. The Review of Economics and Statistics, 84(1), 151-161. DOI:10.1162/003465302317331982

DEMISSEW, S. \& NORDAL, I. (2010). Aloes and Lilies of Ethiopia and Eritrea. 358 pp. http://nhm2.uio.no/botanisk/nbf/temp/Sebsebe $\% 20$ et $\% 20$ Nordal\%202010\%20Lilies\%20-

\%20SCREEN\%2020091220.pdf

HANDARAGAMA, S., RATHNAYAKE, H. \& ULUWADUGE, P. (2013). Women's Economic Participation in Rural Development. International Journal of Education and Research, Vol. 1 No. 8 August 2013. https://www.ijern.com/August-2013.php

HOMANN, S., RISCHKOWSKY, B. \& STEINBACH, J. (2007). The Effect of Development Interventions on the Use of Indigenous Range Management Strategies in the Borana Lowlands in Ethiopia. Land Degradation and Development. 19, 368-387. DOI:10.1002/ldr.845

HURST, M., JENSEN, N., PEDERSEN, S., SHARMA, A. \& ZAMBRISKI, J. (2012). Changing climate adaptation strategies of Borana pastoralists in southern Ethiopia. Working paper no.15 Cali, Colombia: CGIAR Research Program on Climate Change, Agriculture and Food Security (CCAFS). https://mpra.ub.unimuenchen.de/55865/1/MPRA_paper_55865

JICA (2015). Rural resilience enhancement project in the Federal Democratic Republic of Ethiopia. Technical manuals for resilience enhancement in pastoral areas. http://open_jicareport.jica.go.jp/pdf/12237160.pdf

KHANDKER, S. R., KOOLWAL, G. B. \& SAMAD, H. A. (2010). Handbook on impact evaluation: quantitative methods and practice: World Bank. DOI: 10.1596/978-08213-8028-4

LASAGE, R., SEIFU, A., HOOGLAND, M. \& DEVRIES, A. (2010). Report on general characteristics of the Borana zone, Ethiopia. IVM Institute for Environmental Studies.

LEUVEN, E. \& SIANESI, B. (2003). PSMATCH2: Stata module to perform full Mahalanobis and propensity score matching, common support graphing and covariate imbalance testing.

LIVINGSTONE, J. \& RUHINDI, E. (2011). Economic Empowerment for Pastoralist Women: A Comparative Look at Program Experience in Uganda, Somaliland and Sudan. International Conference on Global Land Grabbing.

MCCARTHY, N., KAMARA, A. \& KIRK, M. (2001). The Effect of Environmental Variability on Livestock and Land-Use Management: The Borana Plateau, Southern Ethiopia." Environment and Production Technology Division Discussion Paper 75, Washington DC: IFPRI (International Food Policy Research Institute).

MILKYUNION. (2017). Unpublished report.

ODA, B. K. \& ERENA, B. A. (2017). Aloes of Ethiopia: A Review on Uses and Importance of Aloes in Ethiopia. International Journal of Plant Biology and Research, 5(1), 1059.

https://www.jscimedcentral.com/PlantBiology/plantbiolo gy-5-1059

OYEKANMI, A. M., OLUKEMI, A. R. \& ABOLAJI, F. G. (2014). Physiochemical Properties of African Back Soap, and It's Comparison with Industrial Black Soap, American Journal of Chemistry, Vol. 4 No. 1, pp. 35-37. DOI:10.5923/j.chemistry.20140401.05.

SCHMIDHEINY, K. (2016). The bootstrap. Short Guides to Microeconometrics. University at Basel.

TESFAYE, A. (2006). Access and Benefit Sharing Initiatives in Ethiopia: The Case of Aloe. http://www.absinitiative.info/fileadmin/media/Events/2015/23-

27 February 2015 Addis Ababa Ethiopia/3.2-

Tesfaye-ABS-InitiativesInEthiopia small.pdf

TESHOME, D. D. (2014.). Aloe Soap Value Chain Initiative and Its Effect on Livelihood Diversification Strategy: The Case of Pastoralists and Agro pastoralists of Borana, Southern Ethiopia.

TILAHUN, D. (2015). Assessment of Climatic Variability and Development of Localized Climate Prediction Method for Livestock Production in Borana Area, Southern Ethiopia.

UNDG (2010). Thematic Paper On MDG 3: Promote Gender Equality and Empower Women. United Nations Development Group, March 2010 http://www.oecd.org/social/gender-

development/45341361.pdf

UN. UNITED NATIONS, Department of Economic and Social Affairs, Population Division. (2017). Household Size and Composition around the World 2017 - Data Booklet (ST/ESA/ SER.A/405).

VIRDI, H. K., JAIN, S. \& SHARMA, S. (2012) Effect of locally delivered aloe vera gel as an adjunct to scaling and root planing in the treatment of chronic periodontitis: A clinical study. Indian J Oral Sci,3:84-9. Available from: http://www.indjos.com/text.asp?2012/3/2/84/1064 


\section{$\underline{60}$}

WALKER, C. C. (2017). Aloe Pulcherrima - a Beautiful Ethiopian Endemic. Cactus World, 35(2). https://core.ac.uk/download/pdf/131316992.pdf

WREN, S. \& MAMO, G. (2009). Summaries Report on the Potential for Plant Based Rangeland Enterprises in the Dry lands of Ethiopia. Improving Pastoral Livelihoods and Natural Resource Management through Plant Based Rangeland Products Enterprise Based Rangeland Products Enterprise Based.
WREN, S. (2008). Development of new and/or scape-up of existing. Aloe-based business in Laikipia: submitted to Laikipia wildlife foundation.

YAMANE, T. (1967). Statistics. An Introductory Analysis; (2, Ed.) 